\title{
Gated communities in Bahrain: historical and urban geographies
}

\author{
Zia Salim*
}

California State University, Fullerton, USA

Residential gating is a notable element in cities worldwide, but notable gaps exist in studies of residential gating in smaller cities and the Global South. This article examines the historical and urban geographies of residential gating in the Arab Gulf, using a case study from Bahrain. This research adds new nuance to studies of gated communities by presenting a case study from a smaller city in the Global South and integrating observations and interviews. The results explain the reasons for gated community development in Bahrain and provide insight into gated communities' built and social environments in Bahrain. The article concludes that in ordinary cities, understanding urban development in general, and gated developments in particular, demands attention to their spatiotemporal contexts. Attention to these contexts can provide new insights that contribute to efforts to interpret and theorise contemporary urbanisation processes.

Key Words: gated communities, housing, residential segregation, urban fragmentation, socio-spatial polarisation, Middle East, Gulf cities, migration.

Article Info: Received: August 1, 2019; Revised: November 15, 2020; Accepted: November 22, 2020; Online: May 31, 2021.

\footnotetext{
"Correspondence address

Address: Department of Geography \& the Environment, California State University, Fullerton, 800 N. State College Blvd., CA 92831, USA

Phone: +1-657-278-3875 | Email: zsalim@fullerton.edu
}

(C)2021 Human Geographies; The authors

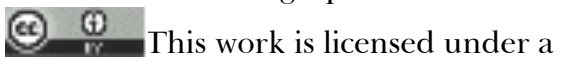

Creative Commons Attribution 4.0 International License. DOI:10.5719/hgeo.2021.151.2 


\section{Introduction}

The spread of gated communities across the globe reflects socioeconomic polarisation and neoliberal urbanisation processes; gated communities are parts of cities as different as Buenos Aires (Borsdorf et al., 2016), Bucharest (Mionel \& Mionel, 2012), and Bangkok (Wissink \& Hazelzet, 2016). In general, the Global North is overrepresented in studies of residential gating as the urban geography literature often treats and theorises gated communities as a housing style inspired by North American models. Simultaneously, larger cities with more influence in global and national urban systems tend to be over-represented in research on urban processes of socioeconomic and spatial polarisation. Gated community researchers have called for a close reading of the historical contexts of residential gating (Bagaeen \& Uduku, 2010), while urban scholars have called for studies of the ordinary smaller cities of the world (Robinson, 2002).

The terms "gating", "gates", and "gated community", as used in this article, draw on several widely cited definitions in the urban studies literature. Caldeira's characterisation of gated communities highlighted the privatisation, enclosure, and monitoring of urban space (1996), while Atkinson \& Blandy defined gated communities as housing developments that restrict public access through the use of "gates, booms, walls and fences" (2005: 177). In the case study presented in this article, the act of walled enclosure of residential space is the key spatial feature, accompanied by several social outcomes, as described later in this article.

Demand for gated communities is driven by factors including security, real or perceived, sense of community, and prestige (Atlas \& LeBlanc, 1994; Lang \& Danielsen, 1997; Wilson-Doenges, 2000; Leisch, 2002; Low, 2003; Cséfalvay, 2011; Hirt \& Petrović, 2011). Gating's outcomes vary, ranging from exclusion and fear of others (Caldeira, 1996; 2000; Low, 2003) to the erosion of the social fabric and a lack of perception of community by residents (Wilson-Doenges, 2000) to increases in property values (Le Goix \& Vesselinov, 2013). Residential gating can be considered a form of enclave urbanism (Sidaway, 2007); the attendant proliferation of gates and walls has implications for the restructuring of private and public space, reduced inter-group contact, and urban social sustainability.

This research responds to several weaknesses in the theorisation of urban areas. Robinson (2006) argued that urban scholars needed to adopt a broader perspective that would account for the diversity and distinctiveness of (overlooked) ordinary cities. Similarly, scholarship has critiqued the overtheorization of cities in Euro-centric and/or US-centric ways (Robinson 2002, Sheppard et al., 2013) and the emphasis on urban economic activities at the expense of other activities and parts of the city (Robinson 2005).

Building on studies of residential gating in the Middle East (Glasze \& Alkhayyal, 2002; Kuppinger, 2004; Glasze, 2006; Geniș, 2007; Alaily-Mattar, 2008; Rosen \& Razin 2008; Rosen \& Grant 2011; Blander et al., 2018), this project seeks to: a) assess the historical roots of contemporary gated communities in Bahrain; b) situate gated communities within the city's contemporary urban geography. Residential land use comprises the largest single category of land use 
within an urban area. By studying housing in an ordinary city in the Global South, this research contributes to more balanced understandings of the modern Gulf and Middle Eastern city, adds an essential and often overlooked perspective to the gated community literature, and contributes to more extensive discussions of planetary urbanisation (Brenner, 2018).

Urbanisation in Bahrain mirrors that of the Gulf (Alhowaish, 2015) as it reflects dramatic transformations brought on by the discovery of oil; the pace of population growth and urbanisation have intensified while oil's role in the economy gradually diminishes. Organic urbanisation has given way to a statecontrolled form (Ben-Hamouche, 2008). In the 1960s and 1970s, modern planning methods were implemented, and extensive infrastructure projects, including a new airport, port facilities, and a ring road, were initiated (Al Ghatam, 2005); a causeway linking Bahrain and Saudi Arabia was completed in 1986. Growing urban areas have engulfed previously distinct villages, blurring the lines between urban, village, and rural (Al-Najjar, 1999, cited in Al-Ghatam, 2005). Village sites are evidenced by organic street morphologies, which contrast with the rectilinear street patterns of the planned areas around them (Al-Ghatam, 2005). Post-war urbanisation in Bahrain was characterised by suburbanisation. Most recently, Bahraini urbanisation has reflected processes of neoliberal urbanisation, including the relaxation of restrictions in the real estate market and the construction of mega-projects and high rise towers (Al Raouf, 2007).

The first of the six Gulf Cooperation Council (GCC) countries to discover oil, Bahrain experienced rapid modernisation that drove increased demand for foreign labour. According to the 2010 Bahraini census, just under $54 \%$ of Bahraini residents and $77 \%$ of the labour force are expatriates; Bahraini citizens are a minority in their own homeland (Dresh \& Piscatori, 2005). Expatriates working in Bahrain are employed on medium- and short-term contracts. The urban landscapes associated with non-nationals cannot be neatly compartmentalised, but socioeconomic status is generally an organising factor: expatriates with higher incomes live in high-rise towers or standalone villas in lower-density suburban zones, and others live in suburban gated communities. Middle-class expatriates may live in (higher or lower density) apartment buildings in neighbourhoods that comprise the bulk of Bahrain's urbanised area. Lowerincome expatriates live in apartments near their places of employment or in older parts of Manama's core, and lower-income expatriates in labour-intensive sectors (e.g. construction) live in labour barracks in peripheral areas and are bused to and from their employment.

Following common usage of the term in Bahrain, this article uses the term "compound" to refer to the gated communities that are the subject of this study: gated housing for foreign white-collar workers and their families. Given that gated community residents in Bahrain are almost exclusively expatriates, this research is as much a study of migration's impact on the Bahraini city as it is a study of socioeconomic polarization and residential segregation. 


\section{Methodology}

This article is based on data from a thirteen-month mixed methods study of gated communities in Bahrain. Extensive field-based mapping surveys were undertaken to assess the number and spatial distribution of compounds. Mapping began with a VGI-based methodology (Salim, 2020) and moved forward to a series of extensive field surveys. Understanding variations in compound form, size, layout, and function gathered during the field mapping contextualised the examination of social dimensions of compound life, provided an understanding of compound locations that helped with interviewee recruitment and sampling, and illuminated the urban processes associated with the proliferation of compounds. Direct and participant observation was carried out at 25 compounds to observe various aspects of compounds, including their built environment, morphology, design, public and private spaces, and relation to the surrounding city. Observation also analysed compound residents, examining aspects including their interaction with each other and relation to the surrounding city. Archival research was conducted in several archives and collections, including the Special Collections at the University of Bahrain's library, Bahrain's National Library in Manama, and an Arabic-language newspaper's archives to understand the historical context of compounds in Bahrain. Relevant research, maps, aerial images, and historical records published in Arabic and English were analysed.

To further analyse the historical context of compounds in Bahrain and to understand the social geographies of contemporary compound residents, formal and informal semi-structured interviews about the historical and social geographies of compound living were conducted with 128 individuals: 68 compound residents, 24 expatriates not living in compounds (for comparison), and 36 stakeholders including compound owners and historians. There were no interview dropouts.

Most stakeholders and some compound and non-compound residents were recruited through their participation in social, educational, governmental, religious, and other organisations. Most of the compound and non-compound residents were recruited through snowball sampling. Although snowball sampling may lead to sample bias, it is the most effective method when researching small or relatively inaccessible communities (Watters \& Biernacki, 1989; Faugier \& Sargeant, 1997), both of which characterise the subjects in this study. Given the subject of this study and the time period in which it was conducted, certain methodological limitations were unavoidable: issues related to compound security and access made it difficult to enter compounds without a prior contact, which affects the number of interviews and surveys that could be conducted, and the demographics of compound residents as a whole are not publicly available. Therefore, the goal for the sampling procedure was not to obtain a representative sample of experiences per se (the degree of representativeness or generalizability is inherently difficult to assess due to the unavailability of demographic data). Instead, the goal of the sampling procedure was to obtain a broad cross-section of resident and stakeholder perspectives. This goal was successfully accomplished. 
As such, the relatively small sample size is sufficient to present valid results and to draw the conclusions presented in this article (Table 1).

Table 1. Summary of interviews

\begin{tabular}{llll}
\hline Group & Time period & Interviews & Individuals \\
\hline Compound residents & Sep. 2011-Aug. 2012 & 73 & 64 \\
& Mar. 2013 & 4 & 4 \\
Non-compound residents & Sep. 2011-Aug. 2012 & 23 & 24 \\
Stakeholders & Sep. 2011-Aug. 2012 & 33 & 33 \\
& Mar. 2013 & 3 & 3 \\
& & Total: 136 & Total: 128 \\
\hline
\end{tabular}

All but one of the in-person interviews were audio-recorded; notes were taken during and after all interviews. The interview audio recordings were transcribed using the Express Scribe software package, and transcripts and interview notes were categorised and coded using the nVivo 9.0 qualitative analysis software. The qualitative data were analysed through manifest and latent content analyses that extracted the main themes and subthemes presented by the participants. Manifest content analysis refers to counting the number of times a particular concept or context is mentioned (Potter \& Levine-Donnerstein, 1999), while latent content analysis examines the underlying meaning of words or contexts (Morse \& Field, 1995). Individual responses to specific questions were coded, and the patterns and topics that emerged were extracted.

\section{Results}

\section{Gated Compounds: Historical Geographies}

Although walls and gates have traditionally characterised residential areas in the Middle Eastern city at various scales, contemporary gated communities in Bahrain are developments of the modern era. The genesis of contemporary gated developments in the Gulf is not the "traditional" Middle Eastern city. Instead, the compounds studied here primarily trace their roots to the oil company worker housing that accompanied the development of a petroleum-exporting economy.

The discovery of petroleum in Bahrain in the 1930s spurred the construction of worker housing in the area of Awali, adjacent to Bahrain's southern oil fields (Figure 1). "Awali" now refers to the large and relatively self-contained housing development, which includes recreational and support facilities. Awali's planned housing for foreign professionals and their families, the first development of its kind in the Arab Gulf, was a model for other oil company towns in the Gulf, including Kuwait Oil Company's Ahmadi development and ARAMCO's large compounds in Saudi Arabia, notably the Dhahran "main camp". Figure 2 depicts the morphology of the Awali development in comparison with Manama, Bahrain's capital and largest city. 


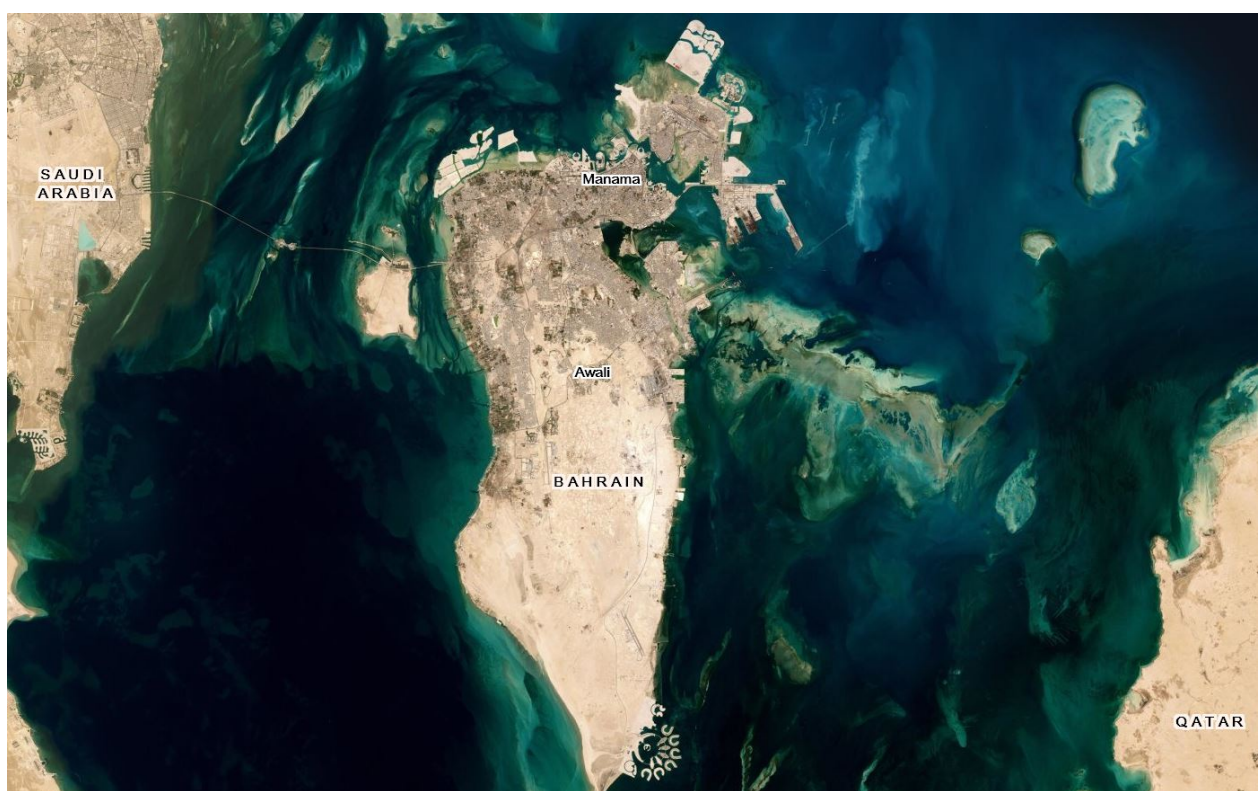

Figure 1. Map of Bahrain, showing locations of Manama and Awali. Source: Author.

Both figures 1 and 2, from a 1956 British map of Bahrain, are at the same scale. Comparing them reveals Awali's large size, lower density, widely spaced housing, modern layout, and exterior wall relative to Manama.

Bahrain's status as the first country in the Arab Gulf to develop a petroleumextraction and export industry made it a regional pioneer. For example, the first international airport in the Gulf was located here, as were the first modern schools in the Gulf for girls. The country became an early node for foreign companies in various sectors (including petroleum, air transport, and banking and finance) conducting business in Bahrain or using it as their regional headquarters. Bahrain's economic growth, and the addition of more advanced service sector jobs in the late 1960s and early 1970s, drove demand for foreign workers, including professionals. Foreign companies (e.g. the British Bank of the Middle East, Citibank, Texaco) required specific housing types for their mid- and upperlevel (foreign) employees, and small-scale gated residential developments began to appear. Foreign companies contracted local property owners to create housing, and property owners began independently developing compounds afterwards. Compounds were thus developed by the private sector, with state involvement limited to the zoning and permitting processes. Compounds allowed local elites to construct and connect to modernity.

Awali's oil company worker housing provides the historical roots of modern gated communities in Bahrain, but housing compounds diffused from the initial seeds planted in Awali. One of the earliest compounds in the city was a housing development that was later named Yateem Gardens. This smaller-scale gated development was located near the city's centre. 


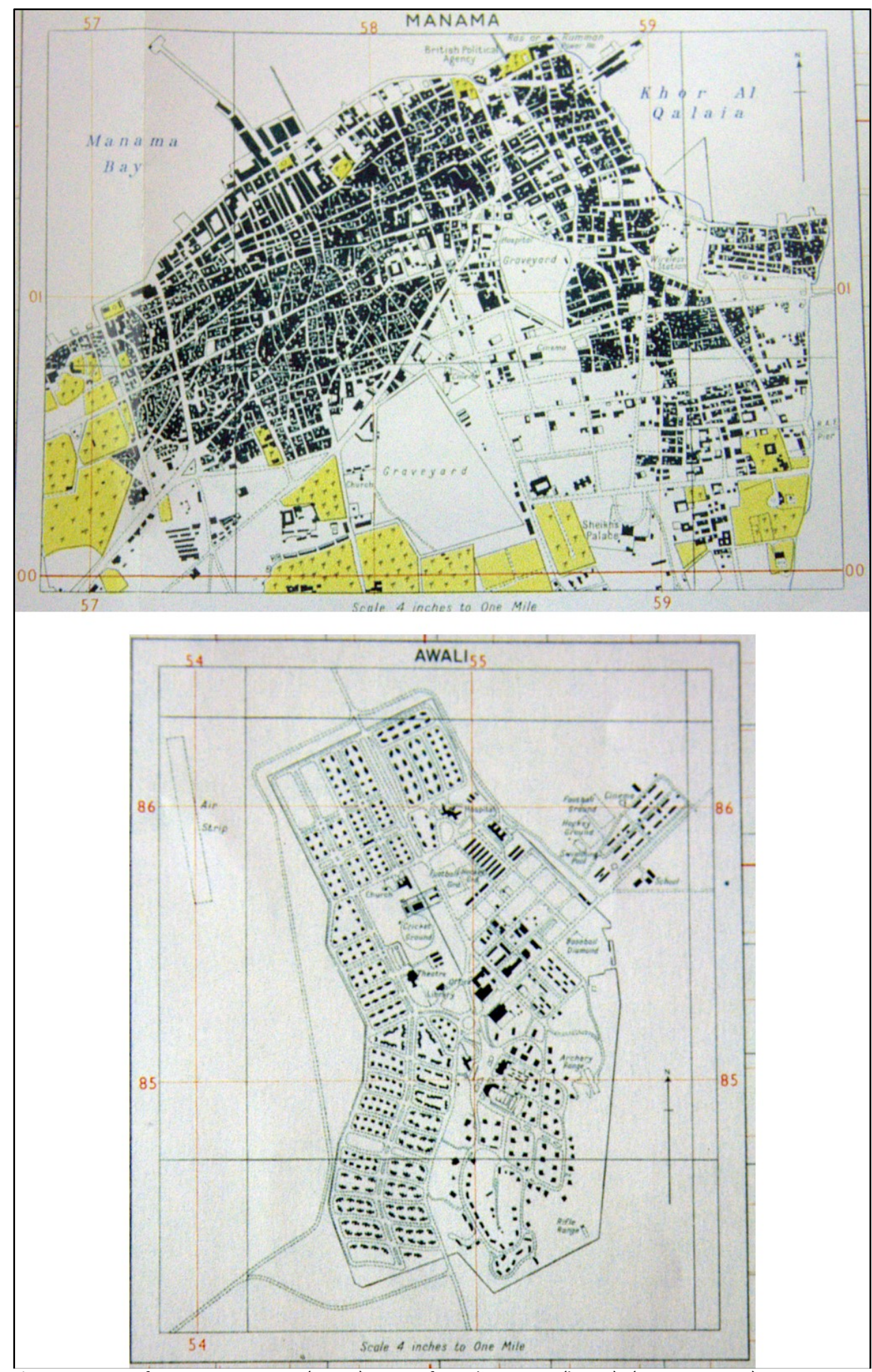

Figure 2. Map of Manama, c. 1956 (upper); Map of Awali, c. 1956 (lower). (Jarman, 2007). 
A member of the Yateem family described the compound's early growth:

The compound was built in 1960. My grandfather purchased the land because he liked the many palm trees growing in the area and he had no plans to develop it. In 1960, British Airways asked my grandfather to build them a house for their employees. Shortly thereafter, British Petroleum asked him to build a guest house for their employees. So the villas were not all built at the same time, which is why many of them have different designs and do not have the cookie cutter feel like other compounds .... It might be safe to say that it was the first compound in Bahrain.

(Email communication, 18 June 2013)

Compounds evolved in terms of location: from Awali, to the compounds near the city's centre, to compounds in suburban locations. In addition to housing for foreign white-collar workers in the oil and other sectors, compounds in Bahrain have two other antecedents, although their influence is relatively more minor. The first antecedent is the military housing associated with the British naval base in Bahrain. The HMS Juffair military base, established in 1935, was Britain's regional naval headquarters from 1967 until 1971 (Scott, 2018). Housing for British service members, especially officers, was constructed in a compound style. The second antecedent is indigenous, as some Bahraini families traditionally constructed multiple homes for extended families within one development some contemporary compounds used to be (and still are) family compounds.

By and large, compound development was an exogenous process. The development of compounds was a direct result of Bahrain's integration into a global economy, as compounds were developed to house foreign workers. Geopolitical and economic events influenced processes of international migration and, in turn, compound construction. Events, as varied as the relocation of financial institutions from Beirut to Bahrain in the wake of the Lebanese civil war and increased US military presence during and after the 1991 Gulf War, increased demand for housing in Bahrain, setting off compound construction booms. Similarly, the 1986 completion of the King Fahd Causeway linking Bahrain and Saudi Arabia stimulated demand for compounds. Because of Saudi Arabia's relatively restrictive cultural norms, some foreign professionals choose to live in Bahrain and work in Saudi Arabia. Bahrain acts, in some ways, as a bedroom community for Saudi Arabia. All in all, the historical genesis of compounds is one key way in which residential gating in the Gulf differs from gated developments in other contexts, such as North America and Europe.

A comparison of the Bahraini case with other contexts in the Gulf illustrates how the geographies of residential segregation diverge, even in countries with similar histories. Compounds in Bahrain differ from their nearest counterparts in Saudi Arabia (Glasze \& Alkhayyal, 2002; Glasze, 2006) in several ways: they are smaller, generally do have not as many amenities, and are less self-contained. These differences reflect, at least in part, the specificity of Bahrain's position as a cosmopolitan and relatively tolerant country (compared to its larger neighbour to the west). The compound "cocoon" is thus not as necessary to make life tolerable 
for expatriates in Bahrain. These findings destabilize the notion of the Gulf as a monolithic region and illustrate the importance of undertaking close readings of the historical and spatial contexts of residential gating.

\section{Gated Compounds: Contemporary Urban and Social Geographies}

Most contemporary compounds are located in suburban areas. This mirrors locational patterns in other contexts, including Argentina (De Duren, 2006), Poland (Mantey, 2017), and China (Sander, 2016). Figure 3, based on the locations of 199 Bahraini compounds identified through extensive field surveys, indicates the density of compounds in Bahrain. Contemporary trends in the morphology, design, and layout of Bahraini compounds are presented below.

\section{Urban Geography: Morphology}

From a morphological perspective, urban areas in Bahrain can be roughly divided into two main categories: newer planned areas and organic areas that are outgrowths of older settlements (e.g. the aforementioned villages). The two upper maps in Figure 4, taken from contemporary zoning maps, illustrate how street patterns and buildings differ in these two types of areas. The lower map in Figure 4 illustrates a compound's morphology. The three images are at the same scale to facilitate comparisons based on house size, inter-house spacing, street width, and overall spatial configuration. Compounds are thus morphologically distinct from planned areas and villages.

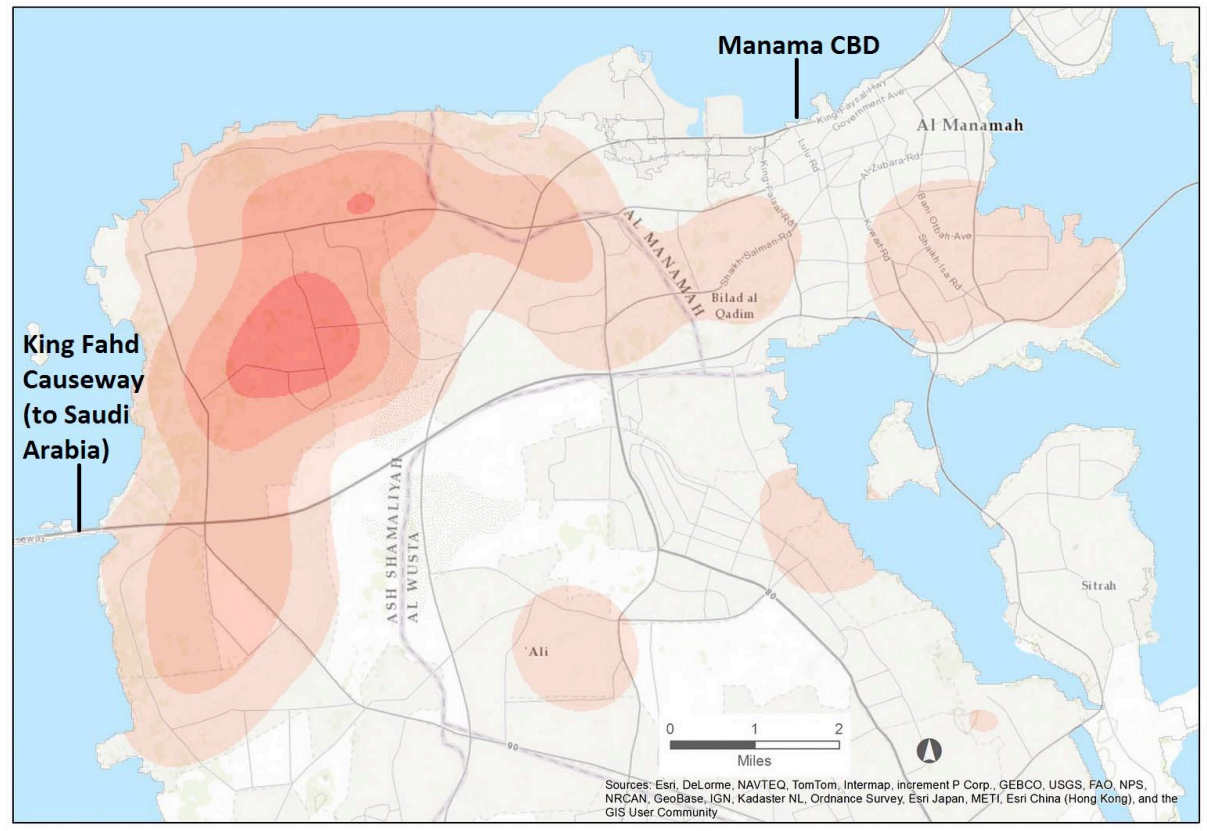

Figure 3. Density of gated housing compounds in Bahrain. Source: Author field surveys. 


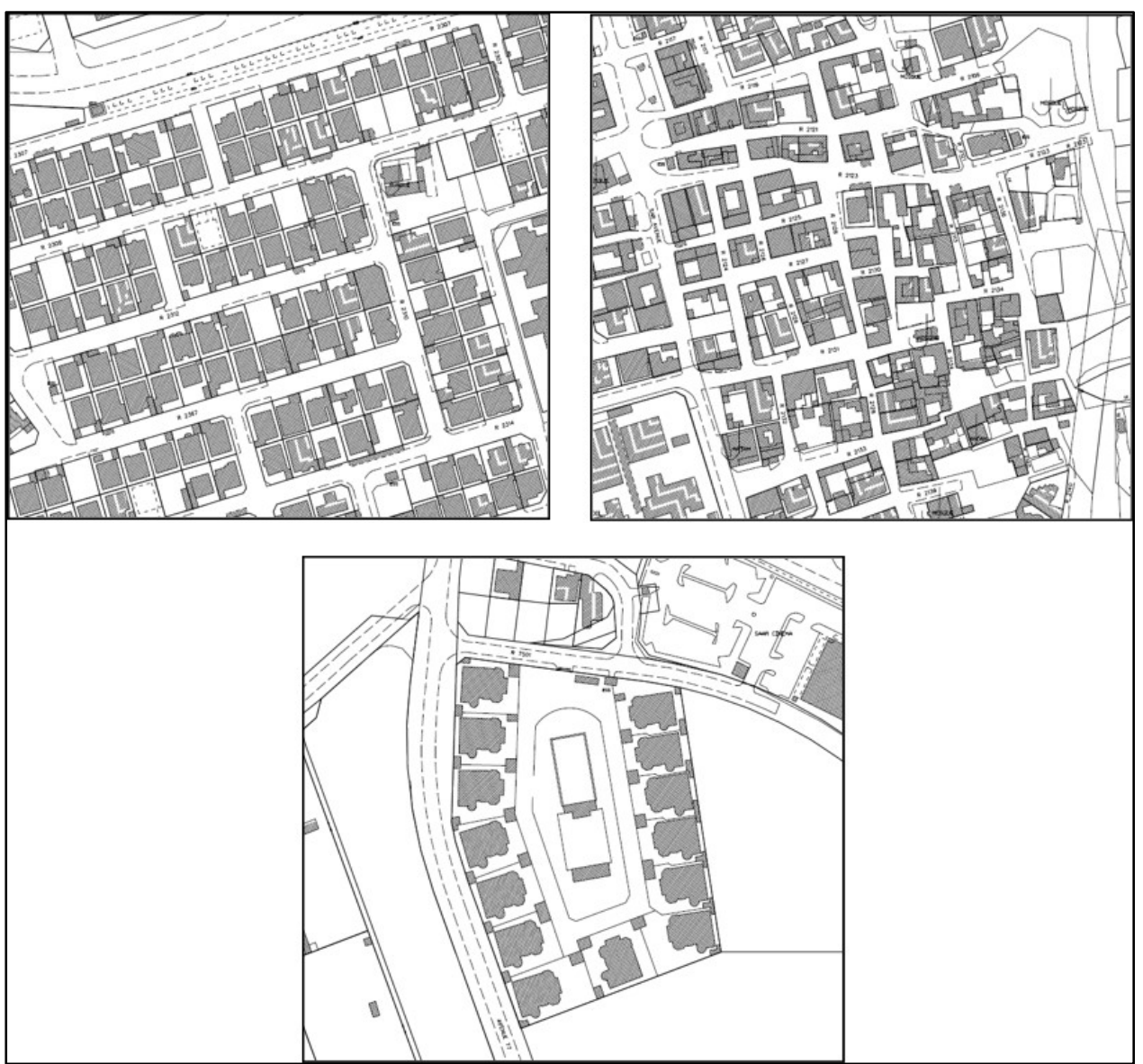

Figure 4. Planned residential area (top left), Village (top right), Compound (lower). Source: Bahraini Ministry of Municipalities Affairs and Urban Planning.

Early planning and zoning guidelines for compound development mandated that a certain percentage (typically about 50\%) of the parcel be set aside as open space. Thus, regardless of the number of houses, the first compounds (called "garden villas" in planning documents) were characterised by low density and plentiful open space.

Property availability for development in suburban locations (supply) and the influx of highly skilled migrants (demand) catalysed real estate development and speculation. As Bahrain's population grew, boosted in part by ever-increasing flows of labour migration, suburbanisation and the numbers of compounds increased in a circular relationship: compounds promoted suburbanisation, and suburbanisation promoted compounds. Of course, not all migrants to Bahrain reside in compounds, and suburbanisation is not limited to compounds. All types of suburban housing have experienced growth. 


\section{Urban Geography: Design}

The bulk of (non-compound) housing in most Bahraini residential areas comprises standalone villas, apartment buildings, or a mixture of both. Although walls and an emphasis on privacy are one of the characteristics of residential areas, compounds impose a larger scale of development in general and of walling in particular: instead of a wall surrounding only one villa, or (in the case of family compounds) three or four villas, compounds can contain larger numbers of villas. The city's structure is affected when developments of this scale are surrounded by walls. In some areas, compounds have developed in a "wall-to-wall" fashion with no non-compound development between them, a "meta-compound" agglomeration that does not articulate with the Bahraini urban fabric.

The outward appearance of compounds (the exterior wall presented to passers-by) is distinctive. Gates and walls (sometimes disproportionately oversized) are the primary external characteristics. Compounds provide varying degrees of security and controlled access: some are highly secured, while others have less stringent security. Security generally resembles that of gated communities in other contexts around the world, including guarded entrances and controlled access, a boom or other barrier restricting road entry, and CCTV cameras, but some forms of security common in the Gulf (e.g. the use of barbed wire and broken glass embedded into the top of the compound's exterior wall) are uncommon elsewhere.

Within the walls, compounds contain individual villas, apartments, or condominiums, ranging in number from as few as 2 to more than 70 . The standardised layout of tract housing is visible from inside and outside the compound walls (Figure 5). Single-family detached villas are the most common type of house. Individual homes in smaller compounds are usually arranged in a linear row; homes in larger compounds are usually laid out around the common recreation facilities. Compounds usually have shared amenities (e.g. swimming pools, community rooms, children's playgrounds, tennis courts); these common spaces are visible in the centre of the compounds in Figure 4 and Figure 5. The compounds that are the subject of this study are exclusively focused on residential space. As such, they are much smaller in scale than, say, the larger-scale condominios cerrados/fechados in Brazil, which may include shops, cinemas, and schools (Caldeira, 2000).

\section{Social Geographies: Patterns and Processes}

Field surveys revealed differences between compounds across Bahrain. Applying classic concepts such as the neighborhood life cycle and filtering to this case study, one finding is that older, smaller, or less maintained compounds (often nearer to the CBD) feature cheaper rents and cater to residents with lower socioeconomic status, while compounds in peripheral suburban areas typically cater to residents with higher socioeconomic status. Further, the characteristics of residents of a particular compound may evolve. 

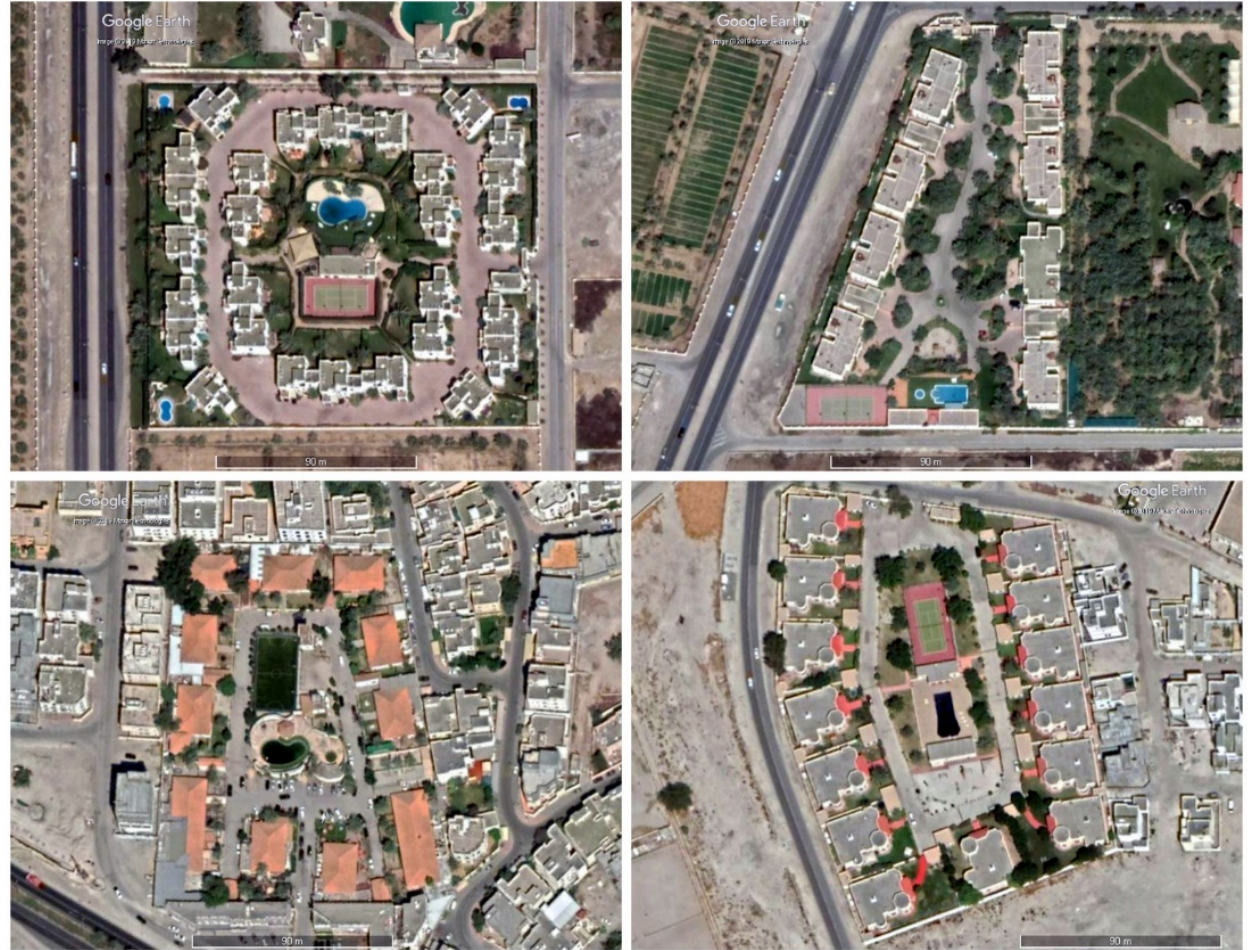

Figure 5. Examples of compound layout; all images are at the same scale. Note the standardized homes. Source: Google Earth.

A compound that began in a peripheral location may eventually cater to a resident of lower socioeconomic status as it ages, as newer compounds are built in more peripheral locations, or as infill brings urbanisation to its gates. This finding has implications for theorising changes in gated communities over time: compounds are not all elite enclaves - variations exist, and compounds may evolve over time in a sort of "gated community life cycle". Compounds in the Gulf in general, and in Bahrain in particular, differ from gated communities in other global contexts in 4 unique ways:

First, nationality overlaps, to a degree, with residential segregation: the whitecollar residents of the compounds studied here are almost exclusively expatriates; very few Bahraini nationals live in compounds. The interviews revealed that the diversity of the nationalities of compound residents varies: some compounds house individuals from only one or two countries, but most compounds contain heterogeneous groups of nationalities. Given that the hierarchical employment structure standard in the Gulf uses nationality as a principal basis for differentiation (Dinkha \& Dakhli, 2009), the finding that compounds are not strictly segregated by nationality is surprising and significant. Expatriates from both Western and non-Western countries live in compounds, as landlords are more concerned with the income of a potential resident than their nationality. As housing developments, compounds are likely to be less structured and 
hierarchical than workplaces. Thus, the residents of compounds may be relatively diverse in terms of nationality.

Second, the contracts of highly skilled migrants often include a housing allowance paid by the employer directly to the landlord (without the employee's involvement). Compounds can thus be conceptualised as conduits for wealth transfer from state or private employers to compound owners.

Third, interviews revealed that the motivations for living in compounds differed from motivations to choose gated communities in other global contexts. For example, some compound residents were assigned housing by their employer and did not choose where they live, a constraint not seen elsewhere in the gated community literature. Further, some interview participants cited factors that differed from gated communities in North America or Europe. For example, several interviewees mentioned that they chose to live in a gated community for access to safe open play space for children, as public parks are unavailable in Bahrain at the scale to which western expatriates are accustomed in their home countries. Additionally, as labour migration has produced neighbourhoods in the Gulf city with high levels of cultural heterogeneity, segregated living arrangements are an established means of adapting to differences (religious, cultural, and economic). Many compound residents reported limited functional linkages with the surrounding Bahraini neighbourhoods, which aligns with the research results on gated communities in South Africa, showing that interactions between those inside and outside the walls were minimal (Lemanski, 2006).

Conversely, the research indicated that factors important in other contexts are unimportant in the Bahraini context. For example, residential enclosure's role in maintaining or increasing property values (Le Goix, 2005) was not a consideration for compound residents since Bahraini property law generally prohibits foreigners from owning property. Overall, the reasons for living in a gated development are similar to other contexts in some respects but very different in others.

Fourth, migration is a key factor that influences the social geographies of compound residents. Employment in Bahrain, as in other parts of the Gulf, can have a high degree of temporal variability, which causes relatively high rates of residential turnover, compared to gated communities elsewhere: residents arrive and depart more frequently than might be the norm in gated communities in other contexts. Obviously, high turnover rates are not specific to compounds, as white-collar expatriates living in apartment buildings or standalone villas can also exhibit a high degree of mobility. However, in a residential neighbourhood, the surrounding population may have a lower degree of mobility than the whitecollar expatriates, leading to a more stable residential base.

An American mother of three who lived in a compound with six villas described how almost the entire compound changed in one summer: For the first three years, we had all the same group of people, six families. And then ... we lost four of them. (Interview, 5 June 2013)

A British interviewee who had lived in a Bahraini compound for ten years described turnover from her perspective: Different people come in and go out. And 
yeah, I was saddened when they leave, but then new people come, and I'm cool with that. You get used to it. (Interview, 5 August 2013)

Thus, mobility and precarity are part of the compound experience. However, the temporally uncertain nature of employment in the Gulf and mandatory agebased retirements mean that even long-term compound residents anticipate the twin displacements of losing a job and having to move. Further, long-term residents experience a dynamic social environment even when they are not mobile, as short-term residents around them come and go. Research revealed commonalities between compounds in Bahrain and gated communities in other contexts. Individual compounds in Bahrain create an economically homogenous residential milieu; while compound residents are relatively diverse in terms of occupation and nationality, they share class and income levels, as they belong to the highly skilled sector of the Bahraini labour force. This mirrors Le Goix's findings in Southern California, where the residents of gated communities had similar income levels (2005). Furthermore, although Bahrain is generally safe, perceptions of additional safety in gated communities were commonly cited by interview participants as reasons to choose them as a living option, also aligning with the gated community literature.

\section{Discussion}

Historicising gated communities is a valuable approach, as an analysis of the genesis of compounds in Bahrain reflects the trajectories underwriting the prevalence of this form of gating: history explains why compounds exist here. Furthermore, historical perspectives connect residential gating with larger trends (e.g. economic, demographic) and provide a basis for comparative studies of gated communities. Studying urban history in parallel with urban morphology and design is constructive in that it illuminates processes and particularities. This follows Brenner and Schmid's argument to understand that the urban is not a universal form or settlement type but is a process (2015).

Gated compounds impact the city as they create a unique urban fragmentation that this article terms "double segregation": compounds are segregated from the surrounding Bahraini city, and compounds that are near each other may house highly skilled migrants of varying socioeconomic classes. As compounds create a mosaic effect in the urban landscape, geographic proximity does not reflect socioeconomic homogeneity: not all compounds are elite enclaves. Further, this article offers the term "meta-compound" to describe the case when multiple compounds develop in a large-scale "wall-to-wall" pattern.

Gating in the Gulf is different from gating in other global contexts, even if the urban form and some of the social dimensions are similar. For example, gated compounds cater to non-nationals, creating "islands" of expatriates within the city, they are accompanied by unique economic arrangements, they are selected as a residential option by some residents for reasons that differ from those in gated communities in other contexts, and their residents experience relatively high 
turnover rates due to the high mobility associated with short-term contracts common in the Gulf. Furthermore, even in countries within the same region, the urban and social geographies of housing compounds are not uniform, highlighting the need to focus on the spatiotemporal context.

Gated communities should be considered dynamic, rather than static, entities: by adapting the neighbourhood life cycle model, one can consider a "gated community life cycle", given that gated communities evolve over time and that change in the larger structure of the city impacts gated communities.

The key contributions outlined above have broad implications in relation to three main theoretical contexts. First, this article contributes to larger theorisations of urban processes. Beyond the specifics of the case study presented in this article, this research aligns with larger-scale calls for cities to be theorised in ways that are not Euro-centric and/or US-centric (Robinson, 2002; Sheppard et al., 2013). Furthermore, this article follows Robinson (2002; 2006) in arguing for a broader perspective that accounts for the diversity and distinctiveness of ordinary cities. In their study of global cities and migration, Price and BentonShort argued that while six of the world's top twenty-five immigrant destinations (measuring percentage of foreign-born residents) are located in the Gulf, the Middle East is "often excluded from the rosters of global cities" (2007, 952). And within the Gulf, cities like Dubai garner disproportionate public and scholarly attention (Elsheshtaway, 2008; Smith, 2010; Ewers, 2017), and the exogenous literature often emphasises the exceptional and the spectacular. As such, the results of this research illustrate the importance of focusing on seemingly mundane aspects of the city and of examining urban processes in smaller (and often overlooked) cities.

Second, this study contributes to the gated community literature by responding to calls for a close reading of the historical contexts of residential gating around the world (Bagaeen \& Uduku, 2010). Studies of gated communities elsewhere in the world have focused on their context and features (Tanulku, 2018; Morales, 2019; Landman, 2020; Roitman \& Recio, 2020) and, in some relatively rare cases, examined the historical contexts of gating (Horta-Duarte, 2012; Scheinbaum, 2010), but this research is the first such study of Bahraini gated communities, although they have long been part of the urban landscape. By drawing on a case study in a (largely overlooked) urban setting, the Persian/Arabian Gulf, this article presents a novel empirical examination of the historical, urban, and social contexts of gated communities. Gated residential developments are prevalent in the Arab Gulf. Paradoxically, however, they are understudied. Given that the extremely limited geographic literature on compounds in the Gulf only examines the case of compounds in Saudi Arabia (Glasze \& Alkhayyal, 2002; Glasze, 2006), this article presents the case of a similar type of exclusionary housing in a particular historical and spatial context. In doing so, it highlights some of the key factors that underlie the similarities and differences between gated communities in Bahrain and other global contexts. As such, it nuances contemporary understandings of compounds in the Gulf, and it 
contributes to understanding and further debate in the (broader) gated community literature.

Third, this study, in examining compounds as enclaves for expatriates, illuminates the dialectical relationship between migration and the city. Friedmann described migration as an important factor in forming the world city hypothesis (1986), but Samers argued that the global/world city literature has not fully dealt with immigration as a topic of study (2002). In a related vein, Beaverstock (2002) called for studies of the geographies of elite enclaves. Bahrain aligns with Price \& Benton-Short's (2007) description of immigrant gateway cities in that it is a hyperdiverse locality linked with similar localities through transnational networks and increasingly comprised of segregated spaces. Brickell \& Datta (2011) suggest that the city provides an essential scale of analysis for studies of transnational processes. This article extends their point and works across scales to illustrate how the neighbourhood can be of equal value in studies of migration and transnationalism: compounds are specific elements in the urban environment that result from the migration of white-collar professionals. Furthermore, as the residents of the compounds studied here are almost exclusively non-Bahraini, this research contributes to a recent (and relatively small) body of geographic scholarship on migration and immigrant spaces in the Gulf (Walsh, 2006; Elsheshtawy, 2008; Glasze, 2006; Mohammad \& Sidaway, 2012). It does this by taking a broadly inclusive approach instead of focusing on a single nationality and by including the perspectives of highly-skilled migrants, highlighting white-collar perspectives instead of focusing on blue-collar labourers. Because the residents of gated compounds in the Gulf are overlooked in the literature, this research improves our understanding of how urban geography shapes the context of the reception of highly skilled migrants.

\section{Conclusion}

Gated communities are a relevant topic given their proliferation and their urban and social impacts. In the world's (smaller) ordinary cities (Robinson, 2006), debates over the drivers and outcomes of urban development in general, and gated housing developments in particular, require close attention to their spatiotemporal contexts. This research presented historical, urban, and social perspectives on residential gating in Bahrain. The fact that it is the first in-depth study of Bahraini gated communities may seem surprising, given the large number and proportion of expatriates and the fact that compounds have been part of the Bahraini urban landscape for decades, but can partially be explained by linguistic and cultural barriers as well as the difficulty of gaining access to conduct social science research in Bahrain (in general) and access to gated communities (in particular). Figure 3, the first map of compound density in Bahrain, shows the suburbanisation of residential gating. Studies of the Bahraini city focusing on economic activity (Ewers et al., 2016) are important, but an emphasis on the economic activities clustered in the centre of the city excludes 
the rest of the city (Robinson, 2005). Given that residential land use comprises the largest single category of land use within the urban area, studying housing makes a valuable contribution to understanding the modern Gulf and Middle Eastern city.

Although no geographic study has examined gated housing for white-collar workers in Bahrain, it is important to consider broader implications beyond this case study. This research offers, through a focus on the spatiotemporal context, new interpretive and analytical approaches to studying the inception and impacts of gated communities; one key value of this research is that these approaches can be applied to studying parallel processes in other types of housing.

A limitation of this research is that statistical information about compound residents is not publicly available (e.g. number, socioeconomic or demographic profile, population proportion in certain areas). Compounds are a part of the larger residential "ecosystem" of housing choices for non-Bahrainis, and compound residents comprise a sizeable proportion of the population in some parts of Bahrain, despite being an overall minority. Estimating the larger impact of these gated developments in Bahrain is difficult given that detailed demographic data is unavailable (e.g. numbers of residents in various types of housing, exact numbers of expatriate residents in small-scale areas in Bahrain). Moving beyond the specifics of this case study, the results presented here also contribute to understandings of larger structural and processual questions: how migration shapes the city, how historic trends underlie urban form, and how socioeconomic polarization is inscribed in the landscape.

\section{Acknowledgemnts}

This research was partly funded by San Diego State University and a Fulbright scholarship. The author gratefully acknowledges Dr. Fernando Bosco for his support of the larger research project, VV for her assistance with field verification, and Dr. Pascale Joassart-Marcelli, Dr. Keith Clarke, and Dr. Helen Couclelis for their helpful feedback. The anonymous reviewers provided insightful comments on earlier drafts of this paper. The standard disclaimer applies. In memory of KDT.

\section{References}

Alaily-Mattar, N. (2008), "Beyond gated communities: Detachment and concentration in networked nodes of affluence in the city of Beirut", Urban Design International, vol.13, no.4, p.263-271.

Al-Ghatam, W. (2005), "Do villages shape our cities?", Paper presented at the $5^{\text {th }}$ International Space Syntax Symposium, Delft, the Netherlands, 6 January 2019, 17 June 2020, shorturl.at/etCY0 
Alhowaish, A. (2015), "Eighty years of urban growth and socioeconomic trends in Dammam Metropolitan Area, Saudi Arabia", Habitat International, vol. 50, p. 9098.

Al Raouf, A. (2007), "Cities in the clouds and pearl towers: Gated vertical residential developments, An analytical study of New Juffair, Bahrain" (in Arabic), Paper presented at Housing Symposium 3, Riyadh, Saudi Arabia, 2022 May 2007.

Al-Najjar, B. (1999), The sociology of the Arabian Gulf: Studies on the problematic of development and modernisation (in Arabic), Dar al-Kunuz al-Adabiya, Beirut.

Atkinson, R. and Blandy, S. (2005), "Introduction: International perspectives on the new enclavism and the rise of gated communities", Housing Studies, vol. 20, no. 2, p. 177-186.

Atlas, R. and LeBlanc, W. (1994), "The impact on crime of street closures and barricades: A Florida case study", Security Journal, vol. 5, no. 3, p. 140-145.

Bagaeen, S. and Uduku, O. (2010), Gated communities: Social sustainability in contemporary and historical gated developments, Earthscan, London.

Beaverstock, J. (2002), "Transnational elites in global cities: British expatriates in Singapore's Financial District", Geoforum, vol. 33, no. 4, p. 525-538.

Ben-Hamouche, M. (2008), "Manama: The metamorphosis of an Arab Gulf city", in Y. Elsheshtawy (ed.) The evolving Arab City: Tradition, modernity and urban development, p. 184-217, Routledge, New York.

Blander, A., Moser, S. and Avni, N. (2018), "Religio-nationalism and "soft boundaries": Urban gating in West Jerusalem and Tel Aviv", Geoforum, vol. 96, p. 227-235.

Borsdorf, A., Hildalgo, H. and Vidal-Koppmann, S. (2016), "Social segregation and gated communities in Santiago de Chile and Buenos Aires: A comparison", Habitat International, vol. 54, p. 18-27.

Brenner, N. (2018), "Debating planetary urbanisation: For an engaged pluralism", Environment and Planning D: Society and Space, vol. 36, p. 570-590.

Brenner, N. and Schmid, C. (2015), "Towards a new epistemology of the urban?", City: Analysis of Urban Trends, Theory, Policy, Action, vol. 19, no. 2-3, p. 151-182.

Brickell, K. and Datta, A. (2011), "Introduction", in K. Brickell and A. Datta (eds.) Translocal Geographies: Spaces, Places, Connections, p. 3-20, Ashgate, Burlington.

Caldeira, T. (1996), "Fortified enclaves: The new urban segregation", Public Culture, vol. 8, no. 2, p. 303-328.

Caldeira, T. (2000), City of walls: Crime, segregation, and citizenship in Sao Paulo, University of California Press, Berkeley.

Cséfalvay, Z. (2011), "Gated communities for security or prestige? A public choice approach and the case of Budapest", International Journal of Urban and Regional Research, vol. 35, no. 4, p. 735-752.

De Duren, N. (2006), "Planning a la carte: The location patterns of gated communities around Buenos Aires in a decentralised planning context", International Journal of Urban and Regional Research, vol. 30, no. 2, p. 308-327.

Dinka, J. and Dakhli, M. (2009), "Perceived discrimination in the Arabian Gulf: The case of migrant labor in Kuwait", Psychology Journal, vol. 6, no. 2, p. 47-59. 
Dresch, P. and Piscatori, J. (2005), Monarchies and nations: Globalisation and identity in the Arab states of the Gulf, I.B.Tauris, New York.

Elsheshtawy, Y. (2008), "Transitory sites: Mapping Dubai's 'forgotten' urban spaces", International Journal of Urban and Regional Research, vol. 32, no. 4, p. 968988.

Ewers, M. (2017), "International knowledge mobility and urban development in rapidly globalising areas: Building global hubs for talent in Dubai and Abu Dhabi", Urban Geography, vol. 38, no. 2, p. 291-314.

Ewers, M., Dicce, R., Poon, J., Chow, J. and Gengler, J. (2016), "Creating and sustaining Islamic financial centers: Bahrain in the wake of financial and political crises", Urban Geography, vol. 39, no. 1, p. 3-25.

Faugier, J. and Sargeant, M. (1997), "Sampling hard to reach populations", Journal of Advanced Nursing, vol. 26, no. 4, p. 790-797.

Friedmann, J. (1986), "The world city hypothesis", Development and Change, vol. 17 , no. 1, p. 69-83.

Geniș, S,. (2007), "Producing elite localities: the rise of gated communities in Istanbul", Urban Studies, vol. 44, no. 4, p. 771-798.

Glasze, G. (2006), "Segregation and seclusion: The case of compounds for Western expatriates in Saudi Arabia", GeoJournal, vol. 66, no. 1, p. 83-88.

Glasze, G. and Alkhayyal, A. (2002), "Gated housing estates in the Arab world: Case studies in Lebanon and Riyadh, Saudi Arabia", Environment and Planning $B$, vol. 29, no. 3, p. 321-336.

Hirt, S. and Petrović, M. (2011), "The Belgrade wall: The proliferation of gated housing in the Serbian capital after socialism", International Journal of Urban and Regional Research, vol. 35, no. 4, p. 753-777.

Horta-Duarte, R. (2012), "It does not even seem like we are in Brazil: Country clubs and gated communities in Belo Horizonte, Brazil, 1951-1964", Journal of Latin American Studies, vol. 44, no. 3, p.435-466.

Jarman, R. (2007), Historical maps of Bahrain 1817-1970, Archive Editions, Slough, England.

Kuppinger, P. (2004), "Exclusive greenery: new gated communities in Cairo", City E Society, vol. 16, no. 2, p. 35-61.

Landman, K. (2020), "Gated communities in South Africa: An emerging paradox", in R. Massey and A. Gunter (eds.) Urban Geography in South Africa, Perspectives and Theory, 6 January 2020, shorturl.at/jpwNU.

Lang, R. and Danielsen, K. (1997), "Gated communities in America: Walling out the world?", Housing Policy Debate, vol. 8, no. 4, p. 867-899.

Le Goix, R. (2005), "Gated communities: Sprawl and social segregation in Southern California", Housing Studies, vol. 20, no. 2, p. 323-343.

Le Goix, R. and Vesselinov, E. (2013), "Gated communities and house prices: suburban change in Southern California", International Journal of Urban and Regional Research, vol. 37, no. 6, p. 2129-2151.

Leisch, H. (2002), "Gated communities in Indonesia", Cities, vol. 19, no. 5, p. 341350. 
Lemanski, C. (2006), "The impact of residential desegregation on social integration: Evidence from a South African neighbourhood", Geoforum, vol. 37, no. 3, p. 417-435.

Low, S. (2003), Behind the gates: Life, security, and the pursuit of happiness in Fortress America, Routledge, New York.

Mantey, D. (2017), "Social consequences of gated communities: The case of suburban Warsaw", The Professional Geographer, vol. 69, no. 1, p. 151-161.

Mionel, V. and Mionel, O. (2012), "Changing the paradigm of living in Bucharest: The economic segregation of the urban privileged", Theoretical and Empirical Researches in Urban Management, vol. 7, no. 4, p. 35-52.

Mohammad, R. and Sidaway, J. (2012), "Spectacular urbanisation amidst variegated geographies of globalisation: Learning from Abu Dhabi's trajectory through the lives of South Asian men", International Journal of Urban and Regional Research, vol. 36, no. 3, p. 606-627.

Morales, E. (2019), "From macro-level policies to micro-level practices: Changing global economic landscapes and the proliferation of middle-class gated communities in Mexico", Transactions of the Association of European Schools of Planning, vol. 3, p. 141-154.

Morse, J. and Field, P. (1995), Nursing research: The application of qualitative approaches, Croom Helm, London.

Potter, W. and Levine-Donnerstein, D. (1999), "Rethinking validity and reliability in content analysis", Journal of Applied Communication Research, vol. 27, no. 3, p. 258-284.

Price, M. and Benton-Short, L. (2007), "Immigrants and world cities: From the hyper-diverse to the bypassed", GeoJournal, vol. 68, no. 2, p. 103-117.

Robinson, J. (2002), "Global and world cities: A view from off the map", International Journal of Urban and Regional Research, vol. 26, no. 3, p. 531-554.

Robinson, J. (2005), "Urban geography: World cities, or a world of cities", Progress in Human Geography, vol. 29, no. 6, p. 757-765.

Robinson, J. (2006), Ordinary cities: Between modernity and development, Routledge, New York.

Roitman, S. and Recio, R. (2020), "Understanding Indonesia's gated communities and their relationship with inequality", Housing Studies, vol. 35, no. 5, p.795-819.

Rosen, G. and Grant, J. (2011), "Reproducing difference: gated communities in Canada and Israel", International Journal of Urban and Regional Research, vol. 35, no. 4, p. 778-793.

Rosen, G. and Razin, E. (2008), "Enclosed residential neighborhoods in Israel: from landscapes of heritage and frontier enclaves to new gated communities", Environment and Planning A, vol. 40, no. 12, p. 2895-2913.

Salim, Z. (2020), "Mapping gated communities: An empirical assessment of Wikimapia data quality", International Journal of Applied Geospatial Research, vol. 11 , no. 3, p. 48-67.

Samers, M. (2002), "Immigration and the Global City Hypothesis: Towards an Alternative Research Agenda", International Journal of Urban and Regional Research, vol. 26, no. 2, p. 389-402. 
Sander, M. (2016), "Shanghai suburbia: Expatriate teenagers' age-specific experiences of gated community living", City, Culture, and Society, vol. 7, no. 4, p. 237-244.

Scheinbaum, D. (2010), "Gated communities in Mexico City: A historical perspective" in S. Bagaeen and O. Uduku (eds.), Gated communities: Social sustainability in contemporary and historical gated developments, Earthscan, London.

Scott, D. (2018), "Britain returns to the Indian Ocean?", The Round Table: The Commonwealth Journal of International Affairs, vol. 107, no. 3, p. 307-316.

Sheppard, E., Leitner, H. and Maringanti, A. (2013), "Provincializing global urbanism: A manifesto", Urban Geography, vol. 34, no. 7, p. 893-900.

Sidaway, J. (2007), "Enclave space: A new metageography of development?", Area, vol. 39, no. 3, p. 331-339.

Smith, B. (2010), "Scared by, of in, and for Dubai", Social and Cultural Geography, vol. 11, no. 3, p. 263-283.

Tanulku, B. (2018), "The formation and perception of safety, danger, and insecurity inside gated communities: Two cases from Istanbul, Turkey", Journal of Housing and the Built Environment, vol. 33, no. 1, p. 151-173.

United Nations (2018), World urbanisation prospects: The 2018 revision, 9 May 2019, https://population.un.org/wup/.

Watters, J. and Biernacki, P. (1989), "Targeted sampling: Options for the study of hidden populations", Social Problems, vol. 36, no. 4, p. 416-430.

Walsh, K. (2006), "'Dad says I'm tied to a shooting star!' Grounding (research on) British expatriate belonging", Area, vol. 38, no. 3, p. 268-278.

Wilson-Doenges, G. (2000), "An exploration of sense of community and fear of crime in gated communities", Environment and Behavior, vol. 32, no. 5, p. 597611.

Wissink, B. and Hazelzet, A. (2016), "Bangkok living: Encountering others in a gated urban field", Cities, vol. 59, p. 164-172. 